to be held outside the proper school-hours. At the German universities, however, laboratory instruction began relatively early, and now stands on a high level compared with other countries. In Austria, science teaching has been considerably developed, but practical classes have not yet been introduced. In Italy; laboratories for the students at the secondary schools are still unknown, but in France they have been building school laboratories for practical work throughout the country ever since the official regulations of 1902 .

In Sweden, the time devoted to natural science is now being increased; scholars can, in most cases, carry out experiments in chemistry, but practical work in physics is almost unknown in the secondary schools belonging to the State. In Norway, there are no secondary school laboratories, although natural science is compulsory. Then again, in Holland, the secondary schools have no practical classes, but the study of physics there is carried further than even in Germany. In Russia, science laboratories are being introduced with considerable success. Until two years ago, physics was the only scientific subject taught in the secondary schools, but since then botany and zoology have been added. The experience gained in Russia in connection with laboratory work has been favourable, in spite of many hampering circumstances. Several recently erected school-buildings have physical departments which have been built regardless of cost; the Physical Institute at St. Petersburg has cost about a million marks, and a still larger one is being built at Moscow.

Dr. Fischer has already shown by his book, "Der naturwissenschaftliche Unterricht in England," that he has an intimate knowledge of English methods of education. His book was the outcome of a visit to this country.

In treating of the teaching of science in the United States of America, reference is made to the alterations in the curriculum of a great number of schools, necessitated by the recent regulation that previous experience in practical physics and chemistry is essential before being admitted to Harvard University and the Lawrence Scientific School.

Finally, various details relating to the universities, technical, medical, and other schools in the countries previously enumerated are given in tabular form; this clearly shows the rapid progress instruction in practical physics has made during the last thirty years. The illustrations include plans and views of laboratories in Munich, Hamburg, Rotterdam, Meppel, Alkmaar, London, \&c.

Although space permits of only a very brief reference to some of the principal points dealt with, it is enough to indicate that this pamphlet can hardly fail to interest and to be of use to those who are concerned in the teaching of chemistry and physics.

The pamphlet by Herr H. Hahn, entitled "Wie sind die physikalischen Schülerübungen praktisch zu gestalten?' like that by Dr. Fischer, is one of the separate parts issued, from time to time, by the well known Zeitschrift für den physikalischen $u$. chemischen Unterricht.

Herr Hahn is undoubtedly one of the many teachers of science in Germany who are convinced that the time has now come to introduce the practical teaching of physics into all schools throughout the German Empire. $\mathrm{He}$ is endeavouring to attract attention to this subject by describing what has been, and is being, done in other countries, more particularly in England and America. This is probably the best way of refuting the objections of those who oppose this advance.

The first portion is devoted to suggestions as to the best methods of conducting practical physics classes in schools and to the aim of such work. It is pointed out that formerly the object was merely to impart knowledge, but that now it is to show the pupil the way he has to set about to acquire knowledge for himself, to confirm laws which are known to him, and also to discover those of which he is as yet unaware. Much rational advice is given regarding the management of practical classes; special stress is laid upon the advisability of avoiding the use of unnecessarily elaborate and expensive apparatus, and of attempting, when possible, to go back to the simple and ingenious means by which a law was first discovered by one of the great men of science. The author advocates students working singly, and argues that, as all boys, as

NC. 1866 , vOL. 72 ] a rule, work at about the same speed, it is possible to put the whole class at the same experiment; usually one finds, however, it is only the most elementary apparatus that can be stocked on so extensive a scale.

Various other questions are gone into, such as the writing-up of note-books in the laboratory, the supplementing of laboratory work by demonstrations, the training of teachers, \&c. From the numerous extracts and foot-notes, one observes that Prof. Hahn has made a most careful and thorough digest of all the existing English and American literature bearing on this branch of science teaching.

The second part deals with laboratories and their fittings, and is illustrated with a number of drawings of fittings, small but clearly executed. These, apparently, are all taken from other books; in fact, about half of them have been reproduced from an English work-Russell's "Planning of Chemical and Physical Laboratories." After some introductory remarks on the size and arrangement of suitable rooms, a description is given of each of the fittings separately, beginning with the simple work-bench for physical laboratories in schools. The ideal is considered to be a bench made to accommodate one worker only, or two in cases of necessity, but it is pointed out that this is too extravagant of floor-space and money to be really practicable. Details of the arrangement, construction, and material of the work-benches are briefiy discussed. All the other fittings usually provided are described, and some useful information is given concerning the actual room itself, schemes for heating and ventilating, the supplypipes, \&c.

Again, one notices that a diligent search has been made for English, American, and German books and papers dealing with the fitting-up of laboratories; from these much information and data have been extracted and compared. The search, however, has as usual been most unproductive; one finds in the list of literature merely some five English books and magazine articles, together with two American and three German ones.

Although only a general survey has been attempted of the arrangement and equipment of school laboratories, it would probably be difficult to find a more complete abstract on this subject, and the pamphlet contains much information which will prove useful to those who are fitting-up laboratories.

\section{STANDARDISATION IN PHARMACY.}

THE principle of standardisation and its embodiment in daily practice marks the most important advance which pharmacy has witnessed within recent years. Standardisation as applied to a crude drug or a preparation is understood to imply that by a method of appropriate treatment ascertained by direct experiment it has been made to conform to a predetermined standard. The required standard may have a physical, chemical, or physiological basis, and may have reference either to one or more definite principles or to a mixture of indefinable substances. The object of standardisation is to secure uniformity of product, more especially in respect of medicinal activity. It is not necessary to hark back more than a generation to see the ever-lengthening strides which pharmacy has taken in the direction of plant analysis and the isolation of definite principles. To this fact the textbooks on materia medica and lectures of twenty-five years ago bear indisputable testimony. Then the maximum of knowledge of the constituents of many of even the best known and most potent drugs was summed up in the statement that they contained a crystalline principle, generally an alkaloid, and a few remotely proximate and chemically unclassified substances. Before standardisation could be brought within the range of pharmaceutical possibility it was necessary to make a more thorough systematic and accurate investigation of crude drugs, with a view of obtaining precise information as to the nature of their constituents.

To this task the younger generation of workers in the field of pharmaceutical research have mainly directed their efforts. Latterly they have occupied themselves more

1 Abridged from the Presidential Address delivered by Mr. W. A. H. July 25 . 
especially in seeking to devise trustworthy processes for the assay of crude drugs and their preparations, and to the extent to which they have succeeded they have contributed in their measure to the benefits conferred on suffering humanity by the healing art.

A few pointed observations reflecting my personal opinion on certain aspects of the question of standardisation may not, I trust, be considered inappropriate with which to conclude my address. In my estimation the aim. should be to produce preparations that will represent the sum total of therapeutic activity of the drugs operated on except in cases where it is desired to obtain the medicinal effects of certain definite principles the physiological action of which is indisputable. As an illustration a preparation of opium may be cited where the presence of narcotine may be considered objectionable. Further, in respect of a given preparation it must be required of the pharmacist to devise suitable processes not only for the estimation of the chief medicinal constituent, but as far as possible the several medicinal constituents and the proportion in which they are present. I would go even further, and say that in the near future it may be necessary to determine certain principles hitherto disregarded, which modify the therapeutic activity of the drug. The pharmacologist may be depended on to point the way, and despite the heavy tax this call for fuller investigation will put upon the resources of the pharmacist, I am encouraged to believe he will prove equal to the demand. Without reflecting on modern methods of standardisation, which undoubtedly have met with general acceptance, I cannot suppress the conviction that their tendency is not free from a suspicion of narrowness. The besetting temptation consists in a disposition to restrict the medicinal properties of a drug to a potent principle, the therapeutics of which are universally recognised by clinicians, and acting on this assumption to proceed to produce a preparation and to standardise it on the basis of the particular principle and with little or no regard to other constituents that may directly or indirectly be of value. For instance, according to present-day knowledge, the chief active principle of the three drugs belladonna, scopola, and henbane is hyoscyamine. If a tincture of each be prepared so as to contain the same percentage of alkaloid or alkaloidal content, will it be seriously contended that therapeutically considered the three are interchangeable, and therefore it is a matter of indifference which of them is selected for use? If the physician finds it a distinct advantage to administer the belladonna tincture in one case and the henbane tincture in another, surely it is because he is satisfied that the two preparations do not produce identical results. May this not be taken as primd facie evidence that there are in the tinctures constituents present, other than hyoscyamine or alkaloidal content, which claim to be reckoned with?

\section{UNIVERSITY AND EDUCATIONAL}

\section{INTELLIGENCE.}

LONDON.-The senate has accepted the offer made by the Secretary of State for the Colonies of the sum of $700 l$. a year for five years for the purpose of instituting a chair of protozoology. Of this sum, 20ol. a year is a contribution from the Rhodes trustees, and 50ol. a year represents a moiety of a grant originally made from the tropical diseases research fund to the Royal Society for the promotion of research work, and by the Royal Society surrendered for the purpose. of .endowing the chair. It was decided to devote the whole amount as salary of the professor, and to set aside a further sum of $200 \mathrm{l}$. a year to defray the cost of assistants and laboratory expenses in connection with the chair.

Mr. Edgar Schuster, the Francis Galton research Fellow in national eugenics, has presented a report containing a preliminary account of inquiries which have been made into the inheritance of disease, and especially of feeblemindedness, deaf-mutism, and phthisis.

Of the five commissioners under the Bill promoted by the university and University College for the determination of the conditions under which the college will be incorporated in the university, which measure received the Royal assent on July II, Lord Justice Cozens-Hardy and NO. 1866 , vOL. 72$]$
Sir Edward Busk were nominated by the university, and Sir John Rotton and Prof. J. Rose Bradford by the college. The remaining commissioner is to be appointed by $\mathrm{His}$ Majesty in Council, and will act as chairman. Sir Edward Fry, late Lord Justice of Appeal, has consented to allow his name to be submitted to His Majesty in Council for this post, and it is expected that the Order in Council announcing his appointment will shortly be published.

Under the will of the late Dr. Nathaniel Rogers, a prize of rool. is offered for an essay on "The Physiology and Pathology of the Pancreas." Essays, preferably typewritten or printed, must be sent to the secretary of the senate by, at latest, May I, 1907 .

THE services rendered to science by the late Dr. T. M. Drown, president of Lehigh University, are to be fittingly recognised, subscriptions having been invited for the purpose of erecting at the university a building to be called Drown Memorial Hall in his honour.

Prof. W. A. TILden, F.R.S., has been appointed dean of the Royal College of Science, South Kensington, in succession to Prof. J. W. Judd, C.B., F.R.S., who retired from the position on July $3 \mathrm{I}$.

Mr. H. J. Hutchens has been appointed demonstrator of bacteriology in the University of Durham. He will continue his work for the Royal Commission on Tuberculosis.

THE subject of the health essay (Durham University) for 1908 is "Injuries and Diseases of the Arteries, Veins and Capillaries, and their Treatment." Essays must be typewritten or printed, and reach the professor of surgery not later than March 31 of the year for which it is to be awarded.

A REPORT on the work of University College, London, for the session 1904-5, was read by Prof. Cormack, dean of the faculty of science, at the assembly of the faculties of arts and laws and of science on July 5. The report records that the Bill for the incorporation of the college in the University of London has passed the House of Lords, and has also passed its first and second readings, as well as the committee stage, in the House of Commons. It is therefore expected that the Bill will receive the Royal assent before the end of the present Parliamentary session. In that case the commissioners, appointed under the Bill to carry out the incorporation of the college in the university, will begin their meetings after the long vacation, and it ought to be possible to complete the actual incorporation by September, 1906. Of the sum of $200,000 l$. required for this purpose, all but $17,000 l$. has been obtained. In the department of applied mathematics the most important event of the session was the generous grant by the Worshipful Company of Drapers of $400 l$. yearly for five years to continue the biometric and research work of the department. This grant has put on a more permanent footing the work already instituted by the same company two years ago. Six memoirs have been specially published as a Drapers' Research Series, and a number of others are in preparation. The work for these has been rendered possible almost entirely by the financial aid provided by this gift. The number of research papers emanating from this department is eighteen, and among them may be noted a paper on "Some Disregarded Points in the Stability of Masonry Dams," which directs attention to a number of complicated and highly important technical questions, and is a valuable contribution both to theory and practice. The research work done in the Pender laboratory during the session has included such practically important matters as :- -additional improvements in means for the photometric measurement of the value of incandescent electric lamps; a long research on the magnetic qualities of alloys, not containing iron, which promises to be of great technical importance; and the invention of instruments called cymometers, which are, in effect, electrical spectroscopes, and enable the frequency of the oscillations in any electric circuit to be measured with great accuracy. Several important contributions to science have come from the department of chemistry; and the list of publications by investigators in this and other departments shows that the activity of the college in producing original work is being maintained. 